\title{
ÍTALO-BRASILEIROS NA ITÁLIA NO SÉCULO XXI: “RETORNO” À TERRA DOS ANTEPASSADOS, IMPASSES E EXPECTATIVAS
}

\author{
Maria Catarina C. Zanini* \\ Gláucia de Oliveira Assis** \\ Luis Fernando Beneduzi ${ }^{* * *}$
}

\begin{abstract}
Nosso objetivo é analisar, partindo de uma perspectiva histórica e etnográfica, algumas situações envolvendo ítalo-brasileiros provenientes do sul do Brasil (Rio Grande do Sul e Santa Catarina) que migraram para a Itália (desde a década de noventa do século $\mathrm{XX)}$. Problematizaremos de que forma este processo foi orientado pela expectativa de "retorno" à terra dos antepassados e aos aspectos simbólicos a ela associados. Pretende-se analisar, também, como a categoria origem (italiana) foi acionada pelos descendentes migrantes e a importância que desempenhou em suas trajetórias migrantistas.
\end{abstract}

Palavras-chave: migração, retorno, identidades.

Este artigo tem por objetivo analisar de que forma descendentes de migrantes italianos do sul do Brasil, provenientes do Rio Grande do Sul e Santa Catarina que se tornam migrantes na Itália tem percebido tal processo. As entrevistas aqui apresentadas foram obtidas na região do Vêneto e na cidade de Trento, na Itália, e com emigrantes retornados da Itália oriundos de regiões de colonização italiana em Santa Catarina e Rio Grande do Sul ${ }^{1}$.

\footnotetext{
* Professora assistente da Universidade Federal de Santa Maria - RS/Brasil.

** Professora associada na Universidade do Estado de Santa Catarina, Florianópolis - SC/Brasil.

*** Professor associado de História e Instituições da América Latina na Universidade Ca' Foscari de Veneza e professor adjunto da Universidade Luterana do Brasil. Canoas - RS/Brasil.

1 Projetos de pesquisa De volta as raízes coordenado pos Luis Fernando Beneduzi (Universidade Ca’Foscari Veneza- Itália) e Os pequenos pontos de partida: das colônias de imigração do sul do Brasil rumo a Itália nesse inicio de século XXI, coordenado por Gláucia de Oliveira Assis (UDESC- Universidade do Estado de Santa Catarina-Brasil) no ano de 2012. Projetos financiados pelo Edital MCT/CNPq/SPM-PR/MDA no 20/2010 - Relações de Gênero, Mulheres e Feminismo. Agradecemos ao Cnpq o financiamento de pesquisa de campo nas cidades de origem em SC e RS, bem como a pesquisa realizada na região do Veneto, na Itália, durante o ano de 2013.
} 
O ponto de partida da pesquisa foi conhecer as trajetórias de emigração dos descendentes que partem rumo à Itália nesse início de século XXI, tendo como ponto desencadeador várias motivações: dentre elas, o desejo de conhecer a terra dos antepassados e nela tentar se colocar como cidadão legitimado, pois grande parte desses descendentes já tinha o reconhecimento da dupla cidadania (brasileira e italiana) ou almejava tê-lo. Estas partidas e chegadas remetem à complexidade do fenômeno migratório contemporâneo, em que os roteiros e projetos são motivados por questões diversas, nos quais subjetividades e objetividades se conectam às historicidades específicas ${ }^{2}$. Nesse fato social $^{3}$ total em que a migração se processa, torna-se perigoso vincular estes deslocamentos a fatores específicos ou mesmo generalizá-los. Um dos objetivos das pesquisas aqui associadas era ouvir estes emigrados e procurar compreender, por meio de suas construções narrativas, como dimensionaram em suas trajetórias de vida a opção pela migração.

Estes imigrantes, como ressalta Sayad ${ }^{4}$, são, antes, emigrantes, e a migração é, como ressalta o autor, um fato social total em que corpos, historicidades, subjetividades e construtos sociais também migram. Trata-se, igualmente, de um percurso em que o trânsito extrapola os limites dos Estados nacionais e as fidelidades nacionais ${ }^{5}$. Para além do "nacionalismo metodológico", como aponta Wimmer e Glick-Schiller ${ }^{6}$, deve-se observar os trânsitos transnacionais em que os pertencimentos se desterritorializam, atravessando fronteiras físicas e também simbólicas. Nestes multi-pertencimentos, em que tempos e espaços distintos se atravessam, estudar os processos de identificação e de percepção dos lugares de origem e de estada (como opção) é algo muito rico, pois são historicidades que se cruzam. Por meio da emigração seus antepassados saíram da Itália para o Brasil no final do século XIX e eles, de certa forma, refazem este caminho, às avessas, no presente. Numa travessia que é geográfica e simbolicamente construída e dimensionada em temporalidades e relações sociais específicas, muitas experiências de vida adquirem sentido para além do processo migratório em si. Nesse cenário, o projeto emigratório dos descendentes, nessa virada do século XX para o XXI, significa não apenas

2 MASSEY, Douglas. The social and economic origins of immigrations; FAIST, Thomas. Transnationalization in international migration implication for the study of citizenship and culture; VERTOVEC, Steven. Super-diversity and its implications; BIGO, Didier. Immigration controls and free movement in Europe; SAYAD, Abdelmalek. Imigração ou os paradoxos da alteridade; SASSEN, Saskia. The mobility of labor and capital.

3 Ibidem.

${ }^{4}$ Ibidem.

${ }^{5}$ BLANC, Linda, GLICK-SCHILLER, Nina; SZANTON, Cristina. Transnationalism, Nation-States, and Culture.

${ }^{6}$ WIMMER, Andreas; GLICK-SCHILLER, Nina. Methodological nationalism and beyond: nation-state building, migration and the social sciences. 
migrar para qualquer lugar, mas sim para a terra dos antepassados, a Itália. Este processo que nossa pesquisa encontrou é diverso daquele de gerações mais novas de ítalo-brasileiros que vão à Itália para encaminhar seu processo de reconhecimento da dupla cidadania pelas vias legais italianas e depois de obterem o reconhecimento partem para outras localidades da Europa e América do Norte, muito embora tenhamos encontrado ítalo-descendentes, estudantes universitários, que decidiram recomeçar suas vidas, no contexto italiano, a partir da formação no ensino superior. Este processo de busca da dupla cidadania para circular pelo mundo é mais comum nas gerações mais jovens e tem ocorrido mais frequentemente nos últimos anos pela falta de emprego e oportunidades de colocação na sociedade italiana. Um dos destinos mais procurados por estes ítalo-descendentes é Londres.

Com os avanços das novas tecnologias de comunicação e transporte os fluxos internacionais de mercadorias, ideias e pessoas se intensificaram na segunda metade do século XX, mas aqui gostaríamos de salientar a importância, especialmente, da rede mundial de computadores, ou a world wid web, que potencializou a troca de dados entre pessoas através da Internet ${ }^{7}$. As novas tecnologias fazem como que os migrantes que trocavam cartas para manter seus vínculos com a terra natal ${ }^{8}$ passem a se conectar online. Assim, permanecem ativos vínculos de afetos, familiares e de pertencimentos locais e grupais, apesar das distâncias. Por meio do Skype, Facebook ${ }^{9}$ e outras ferramentas, são trocadas informações, lembranças e também paisagens entre mundos que circulam, atualizando assim seus pertencimentos. Os jardins e quintais brasileiros e italianos são postados e mostrados, os aniversários, casamentos e momentos dos ciclos de vida que se comunicam. Importante ressaltar que este trânsito transcende questões de gênero e classe social, pois tanto homens como mulheres postam nas redes e publicam suas experiências e pontos de vista.

A migração de descendentes de italianos que têm, nas últimas décadas, elaborado o retorno à terra dos antepassados é um fenômeno que, compreendemos, deva ser observado em ciclos, pois de 2009 para o período mais recente, há também um movimento dos italianos para o Brasil. Isto se deve à crise econômica de 2008 que enfraqueceu as economias europeias e desestabilizou seus mercados de trabalho. Como estes descendentes nem sempre conseguiram se colocar em boas posições no mercado de trabalho italiano, a situação de alguns se fragilizou e como a economia brasileira

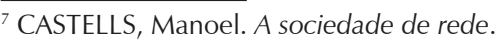

8 ASSIS, Gláucia de O. Estar aqui... Estar lá: uma cartografia da emigração valadarense para os Estados Unidos.

${ }^{9}$ Ferramentas de comunicação on line sem custos em que é possível usar recursos de som e imagem.
} 
apresentou melhoras, a volta ao Brasil se apresentou como um caminho possível. Este novo movimento ainda não foi por nós estudado, contudo tem salientado uma tendência crescente que é a das migrações Norte-Sul. Observa-se que a situação contemporânea tem provocado uma mudança na percepção identitária e da vida no contexto brasileiro: a terra que se abandonou, está se transformando imageticamente, mais uma vez, naquele antigo país da abundância, presente nos relatos migratórios de finais do século XIX.

Um caso interessante é aquele de Paola, natural de Santa Catarina e estudante universitária, na Itália, quando da entrevista, em 2012. Esta jovem, descendente de trentinos, que estava com 26 anos quando colaborou com a pesquisa, tinha decidido, ainda quanto tinha apenas 15 anos, que "retornaria" à terra de seu tataravô. Seguiu um plano muito bem construído para chegar ao seu momento atual, com os estudos financiados por uma bolsa pública provincial italiana. Sua relação com a trentinidade e com Trento sempre foi baseada - até sua vinda - na memória dos encontros familiares no interior catarinense, na rememoração da terra de partida dos seus ancestrais em meio a canções regionais, dialeto, jogos e gastronomia. Ao vir para o ponto inicial da aventura familiar no Brasil, Paola buscava encontrar aquele lugar mágico de seus antepassados. De fato, ela acaba se dando conta que este espaço não existe, que houve uma transformação nas comunidades trentinas no Brasil e na província de Trento; no entanto, seu desejo inicial é uma imigração definitiva e, portanto, a permanência na Itália.

Não obstante os seus objetivos quando da partida - e ela chega casada na Itália, com um não descendente de italianos, mas apaixonado pela cultura da península - a situação presente a leva a refletir sobre as possibilidades de futuro. É muito claro para ela, que sempre mostrou o seu lado pragmático nas escolhas de vida, para além do aspecto afetivo ou etnico-nostálgico, a Itália tem sentido que associa a um emprego, à sobrevivência:

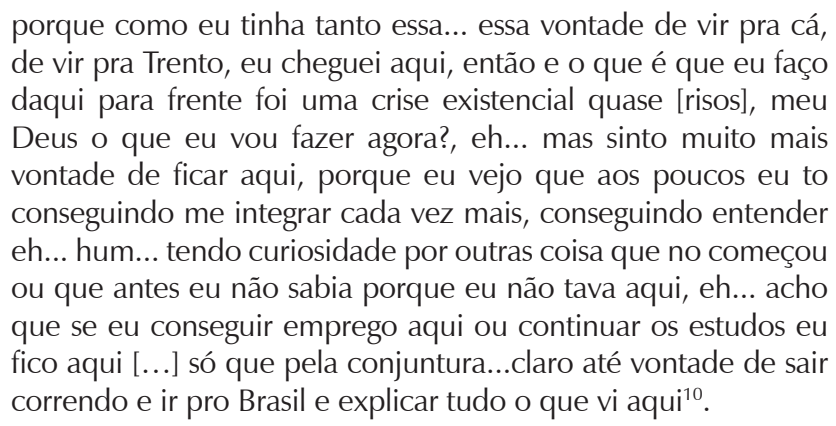

${ }^{10}$ Entrevista realizada por Luis Fernando Beneduzi em fevereiro de 2012, no Trentino Alto Adige, Itália. 
É muito comum, nas entrevistas, que o eventual retorno, por questões que estão muito vinculadas à esfera financeira, não seja apresentado apenas como uma falência do projeto migratório, mas abra a uma realização que pode ser, no caso de Paola, a possibilidade de narrar a sua experiência, e como viveu esse confronto entre a Itália imaginada e aquela vivida, para os parentes e conhecidos no seu estado de proveniência. No entanto, nas entrevistas realizadas, e naquela de Paola com maior força, não se observa uma ideia de arrependimento na escolha da vinda para a Itália. Em seu caso, a questão é ainda mais forte porque, mesmo notando as diferenças, ainda persiste a ideia do encontro, no ato de gostar daquela realidade, como se fosse parte dela, independentemente das pessoas. Ela se sente trentina, porque a paisagem, o clima, a natureza e a arquitetura de Trento são acolhedoras, na sua visão. Deixar aquilo é muito difícil, mas a nova realidade brasileira e também aquela italiana a convidam para refletir:

terminando o curso aqui pra lecionar no Brasil italiano seria muito mais fácil do que eu ficar aqui, que aqui eu vou poder lecionar português ou... italiano com dificuldade porque qualquer italiano, claro tendo um italiano como madrelingua ${ }^{11}$.

Nesse artigo, portanto, narramos/identificamos experiências diversas de retorno. O retorno imaginado dos descendentes à terra de seus antepassados, retorno que marca a volta a uma Itália imaginada e narrada pelos seus bisnonas e bisnonos. Esse encontro com a Itália contemporânea, sua política migratória, a forma como recebe os descendentes, na condição de emigrantes, as vivências de preconceito e discriminação revelam os desencontros dessa experiência migratória. Nesse mesmo tempo e espaço, vários descendentes em função da crise econômica, ou mesmo pelas dificuldades de realizar o projeto migratório, retornam ao Brasil, após um período de permanência na Itália. Esse artigo, portanto, busca problematizar essas experiências diversas e complexas de retorno.

Conforme observaram Assis e Campos ${ }^{12}$ para muitos migrantes: "retornar é mais difícil do que partir". Essa é uma frase recorrente entre os emigrantes. Para os autores, a experiência do retorno é complexa e as categorias "ausente", "retornado", "temporário" e "emigrante" muitas vezes não dão conta de uma experiência que conecta dois lugares, fazendo com que, em muitos casos, os emigrantes passem a viver entre esses dois lugares, configurando uma identidade transnacional. Nesse artigo, Assis e Campos se referiram aos emigrantes de

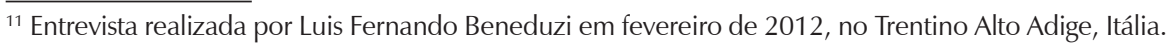

${ }^{12}$ ASSIS, Gláucia de Oliveira; CAMPOS, Emerson C. De volta para casa: a reconstrução de identidades de emigrantes retornados.
} 
Criciúma que emigraram para os Estados Unidos na década de 1990 e que, a partir de 2007, começaram a retornar ao Brasil, em função da crise e da dificuldade de viver indocumentado nos Estados Unidos. Ao analisarem as experiências desses retornados, eles demonstram as dificuldades de retornar, pois como evidencia Stuart Hall ${ }^{13}$, o tempo passou e não se volta nem ao mesmo lugar, nem às mesmas relações sociais. Assim face às dificuldades do retorno à terra natal, muitos desses retornados acabam por re-emigrar ou para os Estados Unidos ou para a Europa, lançando-se num ir e vir que caracteriza essa região como uma região que construiu laços transnacionais

\section{A imigração italiana no Rio Grande do Sul: apontamentos}

A imigração italiana para o Rio Grande do Sul em termos expressivos começa em 1875, quando da chegada das famílias de emigrantes para as três primeiras Colônias Imperiais de imigração: Conde D’Eu, Dona Isabel e Campo dos Bugres, na região serrana do estado em que hoje estão, dentre outras, as cidades de Garibaldi, Bento Gonçalves e Caxias do Sul. Em 1877/78 inicia a colonização da região central do estado, posteriormente denominada de Colônia Imperial Silveira Martins. Eram famílias predominantemente do Norte da Itália, católicas e majoritariamente formadas por camponeses pobres. Havia, contudo, alguns mais letrados e capitalizados, mas eram exceções $^{14}$. Segundo Alvim, teriam migrado, de 1870 a 1920, cerca de 1.243.633 indivíduos ${ }^{15}$. São estimativas, contudo. Naquele momento, o Brasil ainda era um Império e os escravos negros não haviam sido libertos. Aquelas populações contribuíram para a dinamização dos mercados internos no sul do Brasil e também como guardiões de fronteiras ${ }^{16}$. O processo colonizador nesta parte do país foi um processo de povoamento.

Ao chegaram aos lugares de destino, esperavam em barracões e posteriormente eram alocados nos lotes coloniais ${ }^{17}$. Recebiam pequenos auxílios para o início dos cultivos. Os lotes eram, em média, de 25 hectares ${ }^{18}$. Os mesmos foram sendo pagos ao governo brasileiro ao longo dos anos por meio da produção de excedente. Contudo, como as famílias eram numerosas e as terras limitadas, desde o início começou a haver migração das colônias para centros urbanos mais próximos, como Porto Alegre e Santa Maria, por

\footnotetext{
${ }^{13}$ HALL, Stuart. Da Diáspora: identidades e mediações culturais.

${ }^{14}$ RIGHI, José Vicente et alii. Povoadores da Quarta Colônia.

${ }^{15}$ ALVIM, Zuleika Maria Forcione. Brava gente! Os italianos em São Paulo 1870-1920, p. 117.

${ }^{16}$ PINHEIRO MACHADO, Paulo. A política de colonização do Império.

${ }^{17}$ Cf. LORENZONI, Julio. Memórias de um imigrante italiano.

${ }^{18}$ SAQUET, Marcos Aurélio. Os tempos e os territórios da colonização italiana. O desenvolvimento econômico da Colônia Silveira Martins (RS).
} 
exemplo. Os trabalhos nas indústrias e na ferrovia também atraíram migrantes e seus descendentes. Além disto, migravam também para novas colônias à procura de terras para conseguirem, assim, reproduzir a condição camponesa.

Quando da grande migração, em finais do século XIX, a Itália enquanto um Estado nacional unificado era algo incipiente. Não havia a categoria "italiano" formada no território nacional. Esta foi sendo criada e alimentada nas décadas seguintes, especialmente pela política fascista e seu fomento da italianidade al estero ${ }^{19}$. Contudo, a categoria "italiano" fazia sentido no contexto brasileiro em que os migrantes estavam em contato com os nacionais brasileiros e outros grupos migrantes, sendo ainda assim designados pelas congregações religiosas, como aquela dos capuchinhos, no contexto da ex-colônia de Conde d'Eu. Além da experiência migratória comum, aqueles emigrados partilhavam de uma referência comum, a catolicidade, que permitia que se comunicassem e convivessem ${ }^{20}$, além de elementos culturais e linguísticos que, na realidade brasileira, em contraposição aos autóctones, conferiam a eles unidade, construindo um "nós", na relação com os outros grupos étnicos. Adscritivamente, passaram a se autodenominar e serem denominados de "colonos italianos", "gringos", "italianos", entre outros adjetivos. Após décadas de convivência com a sociedade regional e nacional, os processos de identificação passaram por tensões e momentos conflitivos, como, por exemplo, no Estado Novo. Contudo, as fronteiras de pertencimento se mantiveram em níveis diferenciados conforme as localidades e processos repressivos ${ }^{21}$. Além da religiosidade, as organizações religiosas, as beneficentes e profissionais também teriam colaborado para os processos de identificação mútuas ${ }^{22}$ permitindo coesão e auxílio mútuos ${ }^{23}$.

Pensando ainda na questão histórica, mas, sobretudo, na sua releitura desde o presente, pode-se perceber que, mesmo com os processos de controle do Estado Novo, a partir da década de 70 do século passado, começa uma dinâmica de "resgate" de uma determinada cultura entendida como italiana ou, mais especificamente, como talian. Essa realidade, fundada em uma espécie de recuperação do passado colonial e construção de certo olhar sobre o mesmo, busca recuperar aquilo que consideram o koyné dialetal vêneto-lombardo que marcou a maioria das comunidades italianas na região

\footnotetext{
${ }^{19}$ CERVO, Amado Luiz. As relações históricas entre o Brasil e a Itália: o papel da diplomacia.

${ }^{20}$ DE BONI, Luis Alberto; COSTA, Rovílio. Os italianos do Rio Grande do Sul.

${ }^{21}$ ZANINI, Maria Catarina Chitolina. Italianidade no Brasil meridional. A construção da identidade étnica na região de Santa Maria-RS.

${ }^{22}$ AZEVEDO, Thales de. Italianos e gaúchos. Os anos pioneiros da colonização italiana no Rio Grande do Sul.

${ }^{23}$ Ibidem, p. 222.
} 
sul, assim como o relativo extrato cultural que a ele se associa. Desde as comemorações dos 100 anos da imigração italiana, denota-se um forte revival étnico e a busca de reencontrar aquela Itália dos ancestrais. Para além do passado entendido como sucessão de eventos, esse tipo de narrativa dos acontecimentos vai criar uma memória sobre a terra de partida do fenômeno migratório de finais do século XIX e sobre a forma como as comunidades italianas foram se estruturando no contexto do Brasil meridional.

\section{A imigração italiana para Santa Catarina}

Durante o Império, o extremo sul do Brasil constituiu-se em local de destino de imigrantes estrangeiros: primeiro, os alemães e, depois, os italianos e outros grupos étnicos. Dirigiram-se inicialmente para o Rio Grande do Sul, que foi a província que mais recebeu imigrantes italianos, na região sul e depois para Santa Catarina e Paraná. Tal situação inverteu-se no período da "grande migração", quando o governo paulista e os grandes fazendeiros de café passaram a investir na vinda dos imigrantes ${ }^{24}$.

O período de 1870 a 1885 pode ser considerado, segundo Alvim²5, o último período em que o governo brasileiro tentou trazer imigrantes com destino à pequena propriedade, porém o sucesso das colônias foi reduzido. Segundo a autora, estima-se que, entre 1846 e 1860, foram criadas 96 colônias privadas, das quais 66 desapareceram. No âmbito oficial, das 33 colônias fundadas extinguiram-se 29. Diante do fracasso das colônias privadas, a partir de 1867, foram fixadas normas que visavam à diminuição das falhas no sistema de colonização. O governo garantiria: a passagem desde o porto do Rio de Janeiro até o núcleo colonial, a atribuição de um lote de terra a cada família migrante, os alojamentos para os camponeses (alojamentos estes que poderiam ser casas) e a concessão de um pedaço de terra já desmatado para a plantação de gêneros de subsistência, além do fornecimento de sementes, de instrumentos de trabalho e de mantimentos gratuitos nos primeiros 10 dias. Foi nesse contexto que ocorreu a vinda dos italianos para o Brasil.

Os imigrantes, que eram pequenos agricultores, vieram atraídos pela possibilidade de ter acesso à terra e faziam parte de um projeto do Império de povoamento da terra com base na pequena propriedade. Segundo Bassanezi $^{26}$, os imigrantes que saíram da Itália entre 1886 e 1895 marcaram

\footnotetext{
${ }^{24}$ SEYFERTH, Giralda. Imigração e nacionalismo: o discurso da exclusão e a política imigratória no Brasil; BALDIN, Nelma. Tão fortes quanto a vontade: história da imigração italiana no Brasil: os Vênetos em Santa Catarina; BASSANEZI, Maria Silvia C. B. Imigrações internacionais no Brasil: um panorama histórico.

${ }^{25}$ ALVIM, Zuleika. O Brasil Italiano (1880-1920).

${ }^{26}$ BASSANEZI, op. cit., p. 20-21.
} 
o direcionamento do fluxo para além das fronteiras da Europa, dirigindo-se principalmente para o Brasil e a Argentina, até o final dos anos 90, quando o movimento direcionou-se para os Estados Unidos. No Brasil, esse contingente teve como características distintivas: o número mais volumoso de migração familiar que nos outros países e o Vêneto como a região que mais forneceu imigrantes.

No caso da província de Santa Catarina, que em 1870 ainda era uma grande floresta com a população concentrada no litoral, os imigrantes vieram para fazer a ligação do litoral com o planalto, já iniciada pelos imigrantes alemães que chegaram à região do Médio Vale do Itajaí em 1850. Os imigrantes italianos estabeleceram-se inicialmente em torno das colônias já fundadas pelos teutos, como Itajaí, Brusque e Blumenau. Esses imigrantes fundaram ainda outras colônias, como Botuverá e Nova Trento, e dirigiram-se para o sul da província, fundando as colônias de Tubarão, Azambuja, Urussanga e, mais tarde, Criciúma. Essas colônias visavam o povoamento e a interiorização do estado com núcleos de pequenos agricultores.

A política imigratória nesse período representava uma estratégia que se iniciou no Império e permaneceu durante a Primeira República, principalmente após a abolição da escravatura, e que consistiu em articular a política imigratória com os interesses de povoamento e de fornecimento de mão de obra livre e branca numa tentativa de aproximar o Brasil dos padrões de eugenia europeus ${ }^{27}$.

Nas décadas de 1930 e 1940, devido ao esse relativo isolamento geográfico e à sua pouca integração à sociedade nacional, os grupos de imigrantes italianos e alemães do sul do Brasil passaram a ser considerados uma ameaça à construção de nossa identidade nacional. Isto aconteceu porque, com o passar dos anos, esses grupos não se integraram ao restante do país, mantendo sua língua e seus costumes, sem se misturarem à sociedade brasileira.

Nesse período, que corresponde ao período da Segunda Guerra, há uma forte campanha de nacionalização para integrá-los. Os imigrantes foram proibidos de falar sua língua natal e de cultivar seus costumes e suas tradições, os quais ficaram "encobertos" nas memórias dos mais velhos, uma vez que não se incentivava que fossem transmitidas às novas gerações. Segundo Bassanezi ${ }^{28}$ e Seyferth ${ }^{29}$ este foi um período muito difícil para as colônias, pois as políticas

\footnotetext{
${ }^{27}$ SEYFERTH, Giralda. Construindo a Nação: hierarquias raciais e o papel do racismo na política de imigração e colonização.

${ }^{28}$ BASSANEZI, op. cit.

${ }^{29}$ SEYFERTH, Imigração e nacionalismo, op. cit.
} 
com relação aos imigrantes foram marcadas pelo autoritarismo. Os imigrantes, que se mantiveram como grupo étnico no contexto nacional, sofreram com medidas restritivas aos estrangeiros e com a repressão às suas manifestações culturais. Embora permanecessem como grupos étnicos, distinguindo-se dos brasileiros (termo com o qual muitos descendentes referem-se aos descendentes de outras etnias), não havia uma reafirmação explícita e constante da identidade italiana nesse contexto. Dessa forma, a campanha de nacionalização eliminou os canais formais de atualização da etnicidade ao proibir o uso da língua, a publicação de jornais e revistas, as associações, etc.

Nas lembranças de alguns descendentes, o "Tempo da Guerra" representou encobrir a italianidade. A proibição do uso da língua e das manifestações culturais representou para a geração dos filhos dos imigrantes um distanciamento da italianidade. Assim relata uma descendente de imigrantes italianos do sul catarinense:

A minha geração, que tem 50 anos hoje, não tinha essa relação com a Itália, não sabia da onde tinha vindo. Quando a gente cresceu é que a gente começou a pesquisar, porque os nossos pais foram proibidos. A tia Madalena, 80 anos, ela diz que na época de Getúlio tiveram que queimar tudo. A tia Virgínia, do Turvo, tem 98 anos e ela só fala em dialeto. Na época de Getúlio, foram tudo preso, porque falavam o dialeto italiano (Descendente de imigrante italiano - Tia de Lorena - 55 anos).

A escola teve um importante lugar na inserção dos imigrantes na comunidade nacional, pois foi através dela que os descendentes aprenderam (ou não) o português. O aprendizado era difícil, porque falavam a língua da nação de origem em casa e deviam falar o português na escola. Na memória de muitos descendentes, esta foi uma experiência traumática e, por causa disso, muitos deles não ensinaram a seus filhos o alemão, o italiano ou outro dialeto. Os descendentes foram perdendo o uso da língua, mas mantiveram, ou melhor, reinventaram os costumes italianos no Brasil.

É interessante registrar, no entanto, que essas práticas permaneceram no espaço doméstico, no cotidiano familiar, nas narrativas que recontavam as histórias de imigração que atualizavam no âmbito do doméstico e do privado os sentimentos de pertencimento a Itália que era rememorada por seus nonos e nonas. Será no final da década de 70 e ao longo dos anos 1980, que ocorre um processo de rememoração e reconstrução das italianidades, principalmente nas comemorações do centenário nas várias cidades constituídas a partir da presença de imigrantes, os quais através dessas comemorações retomam o discurso étnico, os relatos de imigração, o inventário das italianidades. Essas 
festas marcam o movimento de (re)contar a história da imigração e rememorar os sentimentos de pertencimento étnico.

O movimento de valorização da italianidade nas várias cidades de colonização italiana, em todo o estado de Santa Catarina, especialmente as festas étnicas, ganhou expressão nacional. No caso da região sul do Estado, conforme Savoldi ${ }^{30}$, a redescoberta da italianidade conduziu a um processo de inventário da italianidade, fenômeno observado também nas outras cidades de colonização italiana em Santa Catarina. Desse modo, a cultura italiana, "resgatada" pelas várias associações italianas, refere-se a uma releitura que os descendentes de imigrantes fazem do passado: a imagem do colono rude e agricultor é revalorizada, assim como todos os elementos que ajudam a reconstruir a italianidade. Nesse sentido, as festas italianas, os encontros de família e a elaboração de mapeamentos da italianidade, entre outras manifestações culturais que ocorreram desde meados dos anos 80 nas cidades da região, são elementos que marcam o movimento de "resgate" da cultura italiana $^{31}$. Portanto, os descendentes de imigrantes italianos reconstruíram suas identidades sobrepondo as experiências de seus antepassados vindos da Itália às vivências no Brasil. Essa breve discussão sobre os significados de ser imigrante na região sul é importante para entendermos o contexto em que os novos emigrantes partem das regiões de colonização italiana em Santa Catarina rumo a Europa, muitos deles com a cidadania italiana: eles partem em busca da terra de seus descendentes num retorno imaginado à terra dos nonos e nonas que veremos a seguir.

\section{Por que a Itália?}

Os emigrantes provenientes do sul do Brasil, que migram para a Itália desde meados da década de 1990 e cujo movimento se intensificou nesse início de século XXI, fazem parte de um contingente expressivo de descendentes que buscam através da dupla cidadania uma alternativa à vida nas pequenas cidades de origem. O projeto inclui também a ideia de conhecerem a terra de seus antepassados, bem como usufruírem da possibilidade de circular pela Europa, possibilidade aberta pela dupla cidadania. Nesse sentido, esses emigrantes sentem-se numa certa vantagem étnica em relação a imigrantes de outras nacionalidades e mesmo aos demais brasileiros, pois a documentação, ou seja, o passaporte europeu, em princípio, Ihes daria essa vantagem. Eles

\footnotetext{
${ }^{30}$ SAVOLDI, Adiles. O caminho inverso, p. 40.

${ }^{31}$ ASSIS, Gláucia de O. De Criciúma para o mundo: rearranjos familiares dos novos migrantes brasileiros; ZANINI, op. cit.
} 
sentem-se europeus. Assis ${ }^{32}$ observou como os emigrantes criciumenses se utilizaram da dupla cidadania como estratégia para emigrar para os Estados Unidos na década de 1990 e também para partirem para Europa, embora o destino preferencial fosse os EUA. Da mesma forma, os trabalhos de Savoldi e Renk e Cabral Jr. ${ }^{33}$ analisaram esse movimento de retorno dos descendentes de imigrantes italianos e alemães à terra de seus pais e avós.

Savoldi retrata o movimento de 'retorno' dos descendentes de imigrantes italianos da região sul do estado de Santa Catarina para a Itália. A autora descreve o que denomina de o caminho inverso - a trajetória dos descendentes dos imigrantes que buscam obter a cidadania italiana para resgatar os seus laços com a terra de seus antepassados, bem como procurar oportunidades de trabalho. Segundo essa autora, os descendentes dos imigrantes foram estimulados por programas de intercâmbio com a Itália, que passou a reconhecer a dupla cidadania de descendentes de imigrantes espalhados pelo mundo e expandiu a construção da identidade italiana para além das fronteiras do território. Para os descendentes desses imigrantes, este fato vislumbra um reencontro com a Itália, terra de seus antepassados, e uma possibilidade de reencontro com sua italianidade, agora afirmada positivamente. Assim, nos anos 80 e 90, através de convênios com algumas regiões da Itália ${ }^{34}$, os filhos dos emigrantes retornam à Itália para reencontrar seus parentes, da mesma forma que italianos vêm conhecer um pedacinho da Itália no Brasil. Deste intercâmbio com cidades do sul do Estado de Santa Catarina como Urussanga, Araranguá, Nova Veneza, Cocal do Sul, Rio Jordão e Criciúma, os descendentes dos imigrantes passam por um processo de reconstrução das tradições italianas, revalorizando os brasões de família, a língua, as comidas típicas que se tornam elementos que atraem os italianos para virem conhecer no Brasil uma Itália que não existe mais.

Por outro lado, a dupla cidadania abre para estes brasileiros o mercado de trabalho na comunidade europeia, pois a partir de convênios com algumas cidades na Itália, estes ítalo-brasileiros conseguem contratos de trabalho temporários no verão europeu na Itália e Alemanha e, assim, passam de seis a oito meses na Europa e retornam para o Brasil.

Estes trabalhadores temporários são reconhecidos pelos consulados italianos e, pelo fato de terem passaporte italiano, podem trabalhar sem

\footnotetext{
${ }^{32}$ ASSIS, De Criciúma..., op. cit.

33 SAVOLDI, op. cit; RENK, Arlene; CABRAL Jr., Vilson Antonio. Campesinidade e migração internacional: novas estratégias dos jovens rurais no Oeste Catarinense.

${ }^{34}$ Segundo Savoldi (op. cit.), o sul do Estado vem investindo em festas típicas italianas para criar a sua marca como região e atrair turistas italianos. A cidade de Urussanga é considerada a capital italiana de Santa Catarina e possui um projeto de cidades irmãs (gemellaggio Urussanga-Longrone), que tem por objetivo intercâmbio cultural entre as duas cidades e os dois países.
} 
problemas na Itália. Num contexto de revalorização da identidade italiana, neste encontro de culturas estes emigrantes temporários se surpreendem quando chegam à Itália e são reconhecidos como brasileiros e/ou estrangeiros. Este é um primeiro choque, pois vão se encontrar com aqueles que julgam serem seus patrícios e, no entanto, são distinguidos do grupo, não são reconhecidos como italianos, mas como extracomunitários e por isso objeto de um 'certo preconceito'. Foi percorrendo a trajetória desses emigrantes que partimos para a região do Vêneto na Itália para compreender os projetos de partida, o encontro com a Itália e o retorno ao Brasil.

A pesquisa de campo foi realizada na região do Vêneto e na cidade de Trento, na Itália, nos meses de maio e novembro de 2013 (no período entre fevereiro de 2012 e novembro de 2013). As redes de contato foram seguindo indicações de famílias residentes no sul do Brasil que tinham ou conheciam pessoas e/ou parentes que haviam migrado para a Itália, contatos estabelecidos através das redes sociais, ou sugestões de entrevistados. Por meio desses diferentes canais, pouco a pouco se chegou aos emigrados brasileiros na Itália. Não houve um privilegiamento por classe social, gênero ou geração. Contudo, em sua maioria, encontramos mulheres na faixa etária dos 25 aos 45 anos, com formação universitária e que tiveram o reconhecimento da dupla cidadania após a estada na Itália.

Quando se perguntava aos emigrados as razões do projeto migrantista, eram várias as respostas. Contudo um elemento sempre presente quanto à escolha do destino, a Itália, estava relacionado ao fato de serem descendentes e de desejarem, na época, ter o reconhecimento da cidadania italiana. Para alguns, não conhecer a língua italiana oficial ou mesmo não conhecer a estrutura política e social italiana, não era um empecilho. Havia uma expectativa de partilhamento gerado pelos processos de rememoração e de pertencimentos ao mundo italiano vivenciados no Brasil.

Alguns depoimentos narram as dificuldades de conseguir a documentação e o preconceito enfrentados, mesmo sendo descendentes e brancos, situação pelas quais não imaginavam passar. Assim Marcos narra sua tentativa de documentação:

Entrevistadora: E aí você ficou esse tempo... Quanto tempo levou sua documentação para sair na Itália?

Entrevistado: exatamente 11 meses. Porque eu fui o primeiro, mas eu tive que ir atrás das certidões do meu bisavô, tive que pegar o trem, do trem pegar ônibus. Lá na comunidade de Levati, numa cidadezinha no interior de Bérgamo, esperar abrir a Comuni, a mulher pegar aqueles livros grandes e folhear 
até achar, agora "espera aqui que eu vou tomar café", aquela coisa toda. E tu tinha que "grazie, grazie, grazie...". Então demorou esses 11 meses porque assim... Eu fiz na Comuni, apesar de morar em Peschiera, eu tinha feito na Comuni de Verona na entrada da minha documentação e aquilo estava congestionado. Uma outra coisa que eu senti... O italiano enquanto não tinha essa coisa de... de... cidadania, que é feito na prefeitura, ele ia trabalhar, provavelmente nas sessões, eles chegavam de manhã, o que ele faria, funcionário público? Abria o jornal, internet, lê, contava, batia papo, como o é em qualquer lugar do mundo um funcionário público. Na Inglaterra também é assim. E como começou a haver os pedidos de cidadania e aumentar a solicitação vertiginosamente, eles chegavam de manhã e já tinha 40, 50 pessoas no local. Do lado de fora, pedindo licença, já tavam com as senhas na mão que eles tinham que atender até meio-dia. E o governo não deu esse suporte pra eles, botou mais pessoas ou mais... Eles ficavam estressado então, ficavam nervoso, uma grande oportunidade que eu fui numa delegacia federal, digamos assim que a Questura seria a polícia federal, a mulher me deu o permesso di soggiorno "mas eu quero o permesso de lavoro" e ela assim pra mim: "pega esta merda e vai ver o monumento do (?)" ela disse pra mim. "Vai passear" bem assim o italiano ${ }^{35}$.

O relato de Marcos revela bem as expectativas em relação à dupla cidadania, os constrangimentos e a descoberta de que o documento não lhes garante o reconhecimento como italiano. Uma vez com o passaporte nas mãos Marcos foi para Londres trabalhar, pois avaliou que lá teria melhores oportunidades e não gostou da experiência de ficar na Itália, sem conseguir trabalhar e sendo maltratado pelos italianos, conforme relatou. Em Londres, trabalhou como pizzaiolo, circulou por outros países da Europa, para conhecer e ter mais experiência e, em 2011, retornou para Urussanga para abrir um negócio no ramo de restaurantes junto com sua família. A cidadania italiana, para ele, Ihe permitiu ir e vir, transitar pela Europa e também retornar ao Brasil. O retorno, nesse contexto, teve mais de um sentido: "retornou" à terra de seus antepassados e se desencantou com a Itália que não o acolheu como ele imaginava; por outro lado, a cidadania the permitiu circular livremente pela Europa e retornar ao Brasil, possibilitando a experiência na Inglaterra onde deixou amigos e aprendeu o trabalho que o ajudou no negócio que pretende montar no Brasil a partir dessa experiência. Essas são faces diversas do retorno.

\footnotetext{
${ }^{35}$ Entrevista com Marcos (nome fictício) realizada por Gláucia de Oliveira Assis, em Urussanga com descendente emigrante retornado da Inglaterra. Realizada em dezembro de 2011.
} 
A noção de pertencimento a uma comunidade imaginada ${ }^{36}$, em que uma perspectiva de nação estava acoplada, nos remete a reflexões apontadas por Featherstone acerca dos processos identitários contemporâneos. Diz o autor: "A nação, portanto, vem a ser representada por um conjunto mais ou menos coerente de imagens e lembranças que lidam com as questões cruciais de origem, diferença e distinção de um povo" ${ }^{\prime \prime 3}$. Este processo faz muito sentido quando observamos as noções de pertencimento ao mundo italiano repassadas por seus ancestrais no Brasil. O próprio conceito de cidadania na legislação italiana, vinculada ao jus sanguinis, colabora na construção desta percepção apriorística de pertença. Contudo, ao chegarem e viverem na Itália percebem que lá são percebidos como estrangeiros e não cidadãos italianos legitimados, embora tenham, alguns deles, ao longo do tempo de permanência, a cidadania reconhecida legalmente. O depoimento abaixo é de uma entrevistada que morou um ano no Vêneto e não tinha o reconhecimento da cidadania italiana quando da entrevista. Aliás, ela não sabia se iria solicitar. Quando perguntada sobre se haveria diferença no tratamento delegado a ela pelo fato de ser descendente de italianos, ela responde:

porque que eu acho que não? Hum... Eu acho que tem a questão linguística que por si só já quando alguém vai se apresentar como italiano ou como brasileiro (ehm) ele já independente se diz ou não que tem o passaporte já, já limita assim, outra coisa eu acho que a questão da formação cultural formação universitária, todos os tipos de formação assim formação... que que já não é que eles não levam muito em consideração... Não, não levam muito em consideração porque eu acho que tem muito preconceito com relação ao terceiro mundo por assim dizer. Então, ah porque você tem uma formação no Brasil parece que não é levada muito em consideração...

Pesquisador: e essa questão de ter, por exemplo, ascendência sanguínea você acha que também não é considerada embora a lei considere as pessoas comuns?

Entrevistada: assim, eu acho que no geral algumas pessoas entendem e acham legal, conversam contigo, querem saber a tua história, e tudo mais, assim. Mas de uma maneira geral não é levada muito em consideração, independente se você é, tem ascendência sanguínea ou não as pessoas conversam contigo ${ }^{38}$.

Grande parte dos entrevistados reconheceu a cidadania quando já estava na Itália como imigrante por meio do processo encaminhado nos

\footnotetext{
${ }^{36}$ ANDERSON, Benedict. Imagined Communities.

${ }^{37}$ FEATHERSTONE, Mike. Localismo, globalismo e identidade cultural, p. 18.

${ }^{38}$ Entrevista realizada por Maria Catarina Zanini em novembro de 2012, no Vêneto, Itália.
} 
comuni (equivalentes aos municípios brasileiros) de origem dos antepassados. Processo esse que costuma demorar bem menos tempo em relação àquele que é encaminhado nos consulados brasileiros, que pode levar até 15 anos. No caso acima citado, a descendente de italianos, que tinha 26 quando da entrevista, não pretendia solicitar o reconhecimento da cidadania italiana. Hoje ela retornou ao Brasil e continua seus estudos universitários em Santa Catarina.

Durante o trabalho de campo encontramos experiências diversas de migração: migrantes como Marcos que foram para trabalhar no mercado de trabalho secundário na região do Vêneto, onde trabalhavam em sua maioria em restaurantes, durante a temporada de verão, no caso dos homens, ou no serviço doméstico e cuidado de idosos e crianças, no caso das mulheres. Desse grupo, um contingente retira a dupla cidadania para trabalhar nas sorveterias na Alemanha durante o verão, numa migração pendular que faz com que retornem no inverno para o Brasil e voltem durante o verão para trabalhar novamente. Outra parte, diante da grave crise europeia que se acentuou nos anos 2008-2009, emigrou para a Inglaterra para tentar outras oportunidades de vida e de trabalho, e outros ainda retornaram definitivamente ao Brasil. No entanto, encontramos também um contingente de emigrantes jovens que migraram para fazer cursos de graduação ou pós-graduação na Itália e, nesse caso, a dupla cidadania permite acesso à vida universitária e a uma interação mais cotidiana com a sociedade e a cultura italiana enquanto estudante. No entanto, o que se pode observar nos relatos é que o encontro com a Itália imaginada e narrada por seu nonos e nonas não ocorre sem tensões e conflitos: as dificuldades começam pela língua, pois em geral falam o dialeto e não o italiano; ademais na Itália esses descendentes, embora carreguem na bagagem vários elementos de uma italianidade reconstruída no Brasil, ao chegarem no país europeu, conforme já destacado, não obstante tenham a cidadania, não são reconhecidos como italianos e sim como brasileiros. Nesse contexto, alguns migrantes, que vivenciam situações de discriminação e preconceito, numa conjuntura marcada pela crise econômica, decidem retornar ao Brasil.

Nas narrativas dos emigrantes o retorno aparece como parte do projeto migratório. A maioria dos entrevistados pensava em retornar, em algum momento ao Brasil. Esse projeto é mais claro naqueles emigrantes, principalmente os mais jovens, que migram pensando em fazer uma poupança que lhes permita comprar uma casa, um carro e montar um pequeno negócio. Esse projeto migratório não é formulado de maneira tão explícita por aqueles que migram para estudar, mas entre os que migram para 
trabalhar, ele é mencionado com frequência. No entanto, entre o projeto de migrar e o retorno, as experiências vivenciadas podem alterar esse projeto.

Verônica emigrou em 2007 para acompanhar o marido. Ambos foram para a Itália para tentar tirar a cidadania. Ela, que é descendente, se casou no Brasil com o companheiro, Francisco, para que sua cidadania saísse junto com a dele. Ao longo dos três anos que permaneceram trabalharam duro, primeiro para pagar as dívidas da viagem e depois para juntar dinheiro para realizar o projeto migratório. Assim Verônica e Francisco relatam o momento em que decidiram retornar:

Entrevistador: E o fato de não conseguir a cidadania nesse meio tempo, acelerou esse desejo de voltar? Vocês acham que se tivessem conseguido a cidadania teria sido diferente? Ou não?

Entrevistada: Eu acredito que não. Porque o que pesou foi o emocional não foi nem motivo financeiro. Mas eu digo assim realmente se a gente tivesse ficado mais um dois anos lá a gente ia voltar muito bem. Porque a gente tava ganhando bem, né? Como era só nós dois e era dois salários praticamente, né? A gente ia voltar muito bem. Só que o emocional foi assim fundamental. Não dava mais, muita falta. Coisas simples assim, sabe? Ele, coitado, ele adora jogar o futebol dele. Três anos ele não fez isso. Já pensou? Tu vai lá tu joga, toma uma cervejinha com o teu colega, fala mal da esposa. (...)

Entrevistadora: E quando você decidiu retornar, assim, pra realizar a ideia, pra realizar o projeto aqui no Brasil... Você queria comprar a casa, como você já falou, e tinha alguma outra ideia?

Marido de V.: Não porque... Quer dizer, ter tinha, a ideia principal de ir, como eu falei, pra gente tentar montar alguma coisa. Como a gente viu que ia ficar meio complicado nós nos contentamos com a casa. Porque aqui é muito difícil.

O projeto era fazer uma economia para montar um negócio, mas com o passar do tempo, a cidadania não saiu, pagaram as dívidas, compraram uma casa, um carro e resolveram retornar ao Brasil. Na percepção do casal estava muito pesado viver longe da família e dos amigos no Brasil. Assim, mesmo sem realizar totalmente o projeto e sem a cidadania decidiram retornar para o Brasil.

Siqueira $^{39}$ aborda quatro categorias de retorno ao analisar o regresso dos emigrantes valadarenses dos Estados Unidos para o Brasil. A primeira o retorno temporário, quando o migrante definiu o país de imigração como sua morada, onde tem sua família e investimentos; a segunda categoria é daqueles que retornam ao Brasil, investem em um negócio e acabam perdendo os

\footnotetext{
${ }^{39}$ SIQUEIRA, Sueli. O retorno motivado pela crise na economia norte americana.
} 
recursos investidos e voltam a re-emigrar - o retorno continuado; a terceira retorno permanente é aquele tipo de retorno em que o emigrante consegue estabelecer-se na sua cidade ou país de origem e não pretende emigrar novamente; o quarto seria o "transmigrante", aquele que fica nesse movimento pendular entre os dois lugares, em geral com o green card o que lhe permite múltiplas relações entre o pais de origem e de destino. Nesse artigo, a autora relata ainda os retornados da crise financeira norte-americana e se refere aos mesmos como os retornados da crise, pois têm que antecipar seu projeto de retorno por causa da crise econômica. No caso dos emigrantes que partem das colônias do sul do Brasil rumo a Itália, o retorno ao Brasil pode estar relacionado à crise que se abateu na Itália a partir de 2008, mas revela também certo desencanto com a Itália encontrada, com a experiência de ter a cidadania, mas não ser reconhecido como italiano; por fim, o retorno pode marcar uma certa circularidade, pois muitos ainda voltam regularmente para a Europa, podendo se encaixar na categoria de retorno temporário destacada pela autora.

O retorno, seja para a terra dos antepassados e, depois, para o Brasil, pode ser compreendido, conforme aponta Sayad, enquanto um "fantasma que ronda as consciências"40 em que noções de tempo e de espaço permanecem latentes nos sujeitos que migram.

A ideia do fantasma do retorno, no caso específico dos descendentes de imigrantes italianos, é ainda mais profundo do que aquele pensado/ percebido por Sayad ${ }^{41}$ nos imigrantes provenientes da Argélia, pois se está fazendo referência a um grupo de sujeitos que não viveu fisicamente partida e retorno. Esta volta, da qual se busca refletir, não é analisada enquanto vivência objetiva do duplo deslocamento. Diferentemente, pensa-se a um processo vinculado ao mundo da sensibilidade e do imaginário, o retorno a um espaço que nunca foi vivido fisicamente, mas, dado a conhecer através das histórias familiares e das narrativas produzidas ao interno do grupo étnico, constitui-se em parte de quadros sociais de memória, pensando em Halbwachs ${ }^{42}$. A noção de individualização do processo imigratório, no descendente contemporâneo, é construída a partir das dinâmicas familiares que transformam a experiência passada em um fato continuado, em um "nós fizemos, nós imigramos". Dessa

\footnotetext{
${ }^{40}$ Diz o autor, "A questão do retorno- que pode constituir um verdadeiro objeto de estudo, pois ela é principalmente da ordem do fantasma que ronda as consciências- representa uma das dimensões essenciais dessa antropologia, na medida em que pressupõe necessariamente vários modos de relações: uma relação com o tempo, o tempo de ontem e o tempo do futuro, a representação de um e a projeção do outro, sendo estreitamente dependentes do domínio que se tem do tempo presente, isto é, do tempo cotidiano da imigração presente..." (SAYAD, op. cit, p. 12).

$41 \mathrm{lbidem}$.

${ }^{42}$ HALBWACHS, Maurice. A memória coletiva.
} 
forma, um lugar não visto nem vivido é transformado, pela memória que sobre ele foi construída nas narrativas intra-familiares, nas festas étnicas ou nas falas dos memorialistas da imigração, em experiência pessoal.

Essa marca do espectro dos ancestrais é muito viva em Paola, já apresentada anteriormente, que entende a Península Itálica, antes de sua partida, como um lugar mágico, uma espécie de país encantado da infância, recordando a convivência com tios e avós, nos momentos de sociabilidade familiar, quando "as coisas" da imigração eram contadas. Essa questão era tão forte que ela decidiu, em 2003, fazer um curso de "Mecânica Polivalente", ainda em Santa Catarina, algo completamente fora do seu interesse formativo, vinculado à área linguística, porque era uma atividade oferecida pelo governo da Itália:

eu disse, olha, não me interessa. Eu não sabia nem o que era, mas disse poxa, o governo da Itália está financiando pra descendentes de italianos no geral. Aí eu fui lá, tinha seleção porque eram 20 vagas. Me esforcei, fui lá, consegui, passei em primeiro na seleção. Feliz da vida. Fiz essa experiência. Também foi forte, porque foi a primeira vez que eu tive contato com italianos da Itália ${ }^{43}$.

O curso para Paola constituiu-se na primeira oportunidade de ter um contato mais próximo com aquela realidade vivida enquanto experiência narrativa familiar. Pela primeira vez, como ela afirmou em sua fala, teve contato com italianos da Itália. Isso nos remete a duas percepções: (1) ela se entendia, enquanto indivíduo e enquanto representante de um grupo, como italiana; e (2) em seu conceito de italianidade existem duas tipologias, uma brasileira e outra peninsular. Esse curso, de alguma maneira, transforma-se na primeira oportunidade que a entrevistada tem de conferir a veracidade do quanto vivido mnemonicamente no espaço familiar. Pode-se dizer que é o primeiro passo em sua viagem de "retorno", onde ela, junto com seu tataravô, começa a fazer as malas para voltar àquela realidade tão íntima, mesmo se jamais vivida objetivamente.

É muito emblemático, na fala de Paola, aquilo que ela pensa que irá encontrar na Itália, ou seja, a imagem cristalizada das narrativas familiares, um mundo que permaneceu imutável, esperando para ser revisitado: "Poxa, se eu fosse pra Itália seria uma forma de eu conhecer esse passado, de que tanto se falava na minha família, e o crescimento pessoal, assim, já na época eu pensava nessa maneira" ${ }^{\prime 4}$.

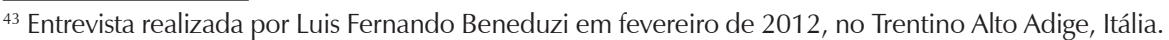

${ }^{44}$ Entrevista realizada por Luis Fernando Beneduzi em fevereiro de 2012, no Trentino Alto Adige, Itália.
} 
Na realidade, a entrevistada busca encontrar em cada detalhe dos arredores de Trento, em cada fachada ou edificação, uma associação com aquele espaço passado, o qual foi vivido pelo seu tataravô. Nas suas andanças, em cada paisagem, em cada igreja, ela se pergunta se o seu ancestral teria visto aquela imagem, teria vivido aquele lugar. Uma resposta afirmativa significaria que ela estava pisando naquele solo sagrado das histórias familiares ouvidas na casa de seu bisavô, na zona de colonização italiana do estado de Santa Catarina:

Eu olho as montanhas, eu digo, poxa o meu tataravô viu isso, ele acordava e via isso, porque ele nasceu aqui pertinho, [...]. Poxa, ele cresceu, poxa será que ele passou por essa igreja, poxa vou ver se esta igreja é de antes ou depois, quando é que ela foi construída ${ }^{45}$.

De qualquer forma, ela se dá conta que aquele mundo imaginado na partida e buscado na sua estadia em Trento não existe da mesma forma que ela o havia construído imageticamente, a partir das memórias de família no Brasil. Ela não expressa isso em uma leitura do espaço edificado, mas na forma de se relacionar dos diferentes indivíduos encontrados, nas características humanas da população local, que se diferenciava daquela dos ítalo-brasileiros de sua zona de referência para a elaboração de sua italianidade:

pensando assim que eu ia encontrar pessoas aqui como toda a humildade camponesa que a gente via dos descendentes no Brasil. De você ver o agricultor, que tem a casinha lá, que tá com o fogão a lenha, que é receptivo, que, ao mesmo tempo, é tão humildade, que te diz, olha eu plantei toda essa uva aqui, mas eu não sei nada de agricultura ${ }^{46}$.

Essa imagem do agricultor humilde, talvez aquela forjada sobre seu tataravô na intimidade familiar, não é parte do trentino contemporâneo, diferentemente daquilo que ela esperava encontrar, quando partiu em busca do passado de seus ancestrais, em uma região sem tempo. Continuando sua fala, no entanto, ela se dá conta de duas coisas: (1) houve um processo de transformação social e aquela experiência de seu antepassado ficou perdida; (2) talvez ela ainda não tenha ido ao lugar certo, na localidade exata, naquela hospedaria proustiana "Au tempe perdù". De qualquer maneira, é interessante observar o conjunto de suas leituras, de como este fantasma do passado é importante na construção de seu projeto migratório e de como ele vai sofrendo um processo de reelaboração no confronto entre uma Itália imaginada e uma outra vivida.

\footnotetext{
${ }^{45}$ Entrevista realizada por Luis Fernando Beneduzi em fevereiro de 2012, no Trentino Alto Adige, Itália.

${ }^{46}$ Entrevista realizada por Luis Fernando Beneduzi em fevereiro de 2012, no Trentino Alto Adige, Itália.
} 


\section{Considerações Finais}

Como observado ao longo deste artigo, o retorno é uma categoria muito importante para os descendentes de italianos que migram. Observa-se o quanto o conhecimento (e reconhecimento) do mundo das origens é importante. O desapontamento de muitos com a Itália contemporânea e a forma como os ítalo-brasileiros são tratados não impede que queiram permanecer na Itália e nela estabelecer seus projetos de vida. Inclusive, em alguns casos, elaboram justificativas para o tipo de acolhida, seja por uma questão de diferença cultura seja por um conceito fluido e amplo de "timidez", associado às populações do norte da Península Itálica.

Por meio de casamentos ou de estabilidade financeira, a permanência na Itália é vislumbrada em longo prazo. O estabelecimento de relações estáveis com italianos natos, como o casamento, por exemplo, é um dos elementos mais considerados na permanência na Itália. Isto porque, para além das dificuldades de colocação no mercado de trabalho ou de integração, estes entrevistados valorizavam muito as relações afetivas estabelecidas com seus cônjuges e retornar somente seria possível se fosse um projeto do casal. O vínculo com as famílias extensas dos cônjuges, embora nem sempre marcante, era também apontado como fator de permanência. Alguns cônjuges possuíam pais idosos e que necessitavam de sua permanência na Itália, portanto, as decisões deveriam girar em torno de projetos menos individuais e mais coletivos.

Por outro lado, encontramos vários imigrantes, individuais ou em família, que estavam se preparando para o retorno ao Brasil, fazendo desta categoria algo mais complexo ainda. A nova realidade brasileira, ou melhor, a imagem produzida sobre o Brasil no plano internacional, tem contribuído não somente para uma nova percepção do brasileiro no contexto italiano, mas, também, para uma nova visão do Brasil para os próprios imigrantes, funcionando, desta maneira, como um fator de atração. Nesse sentido, o novo deslocamento está marcado pela busca de aproveitar a atual onda positiva brasileira, vista mais uma vez como terra della cuccagna - na qual quem menos trabalha mais ganha - parafraseando um provérbio de finais do século XIX, que estava na boca de muitos italianos que partiam para o Brasil.

\section{Bibliografia}

ALVIM, Zuleika Maria Forcione. Brava gente! Os italianos em São Paulo 1870-1920.

São Paulo: Brasiliense, 1986.

O Brasil Italiano (1880-1920). In FAUSTO, Boris. Fazer a América. São Paulo: Edusp, 1999, p. 383-419. 
ANCARANI, Umberto. Monographia sobre a origem da ex-colonia italiana de Silveira Martins 1877-1914. Revista Commemorativa do Centenário da Fundação da Cidade de Santa Maria-RS 1814-1914 [S.L:s.d].

ANDERSON, Benedict. Imagined Communities. London: Verso, 1983.

ASSIS, Gláucia de O. De Criciúma para o mundo: rearranjos familiares dos novos migrantes brasileiros. Florianópolis: Editora, Mulheres, 2011.

. Estar aqui... Estar lá: uma cartografia da emigração valadarense para os Estados Unidos. In REIS, Rossana Rocha; SALES, Teresa. Cenas do Brasil Migrante. São Paulo: Boitempo, 1999.

ASSIS, Gláucia de O.; CAMPOS, Emerson C. De volta para casa: a reconstrução de identidades de emigrantes retornados. Revista Tempo e Argumento. Florianópolis, v. 1, n. 2, p. 80-99, jul./dez. 2009.

AZEVEDO, Thales de. Italianos e gaúchos. Os anos pioneiros da colonização italiana no Rio Grande do Sul. Porto Alegre: Instituto Estadual do Livro, 1975.

BALDIN, Nelma. Tão fortes quanto a vontade: história da imigração italiana no Brasil: os Vênetos em Santa Catarina. Florianópolis: Insular, 1999.

BASSANEZI, Maria Silvia C. B. Imigrações internacionais no Brasil um panorama histórico. In PATARRA, Neide (coord.). Emigração e Imigração internacionais no Brasil contemporâneo. São Paulo: FNUAP, 1995, p. 1-38.

BIGO, Didier. Immigration controls and free movement in Europe. International Review of the Red Cross, v. 91, n. 875, 2009, p. 579-591.

BLANC, Linda; GLICK-SCHILLER, Nina; SZANTON, Cristina. Transnationalism, Nation-States, and Culture. Current Anthropology, v. 36, n. 4, Aug.-Oct. 1995, p. 683-686.

CASTELLS, Manuel. A sociedade de rede. A era da informação: economia, sociedade e cultura. São Paulo: Paz e Terra, 2006.

CERVO, Amado Luiz. As relações históricas entre o Brasil e a Itália: o papel da diplomacia. Brasília: Editora da Universidade de Brasília; São Paulo: Instituto Italiano de Cultura, 1992.

DE BONI, Luis Alberto; COSTA, Rovílio. Os italianos do Rio Grande do Sul. Porto Alegre/Caxias do Sul: EST/Universidade de Caxias do Sul, 1984.

FAIST, Thomas. Transnationalization in international migration implication for the study of citizenship and culture. Ethnic and Racial studies, v. 23, Issue 2, p. 189222, 2000.

FEATHERSTONE, Mike. Localismo, globalismo e identidade cultural. Revista Sociedade e Estado, v. X, n. 1, jan-jul 1996, p. 9-42.

GLICK-SCHILLER, Nina; BASH, Linda; BLANC-SZANTON, Cristina. From immigrant to transmigrant:theorizing transnational migration. Anthropological Quarterly, v. 68, n. 1, 1995, p. 48-63.

. Towards a transnational perspective on migration. New York Academy of Sciences: New York, 1991. 
HALBWACHS, Maurice. A memória coletiva. São Paulo: Vértice, Editora Revista dos Tribunais, 1990.

HALL, Stuart. Da Diáspora: Identidades e mediações culturais. Belo Horizonte: UFMG; Brasília: representação da UNESCO no Brasil, 2003.

LORENZONI, Julio. Memórias de um imigrante italiano. Porto Alegre: Sulina, 1975.

MASSEY, Douglas. The social and economic origins of immigrations. Annals of the American Academy of Political and Social Science, v. 510, 2000, p. 60-72.

PINHEIRO MACHADO, Paulo. A política de colonização do Império. Porto Alegre: EDUFRGS, 1999.

RENK, Arlene; CABRAL Jr., Vilson Antonio. Campesinidade e migração internacional: novas estratégias dos jovens rurais no Oeste Catarinense. Trabalho apresentado no XXIV Encontro Anual da ANPOCS, GT-9 - 'Migrações Internacionais', Petrópolis, RJ, 23 a 27 de outubro de 2000.

RIGHI, José Vicente et alii. Povoadores da Quarta Colônia. Porto Alegre: EST, 2001.

SAQUET, Marcos Aurélio. Os tempos e os territórios da colonização italiana. O desenvolvimento econômico da Colônia Silveira Martins (RS). Porto Alegre: EST, 2003.

SASSEN, Saskia. The mobility of labor and capital. Cambridge: Cambridge University Press, 1988.

SAVOLDI, Adiles. O caminho inverso: a trajetória dos descendentes de imigrantes italianos em busca da dupla cidadania. (Dissertação de Mestrado). Florianópolis, Programa de pós-graduação em Antropologia Social, UFSC, 1998.

SAYAD, Abdelmalek. Imigração ou os paradoxos da alteridade. São Paulo: Edusp, 1998.

O Retorno. Elemento constitutivo da condição do imigrante. Revista Travessia, ano XIII, n. especial, 2000, p.1-34.

SEYFERTH, Giralda. Construindo a Nação: hierarquias raciais e o papel do racismo na política de imigração e colonização. In MAIO, Marcos Chor; SANTOS, Ricardo Ventura. Raça, ciência e sociedade. Rio de Janeiro: FIOCRUZ/CCBB, 1996, p. 41-59. . Imigração e cultura no Brasil. Brasília: EdunB, 1990.

. Imigração e nacionalismo: o discurso da exclusão e a política imigratória no Brasil. In CASTRO, Mary G. (coord.). Seminário Internacional Migrações Internacionais - contribuições para políticas Brasil, 2000. Brasília: CNPD, 2001, p. 137-150.

SGANZERLA, Claudia Mara. A lei do silêncio. Passo Fundo: UPF, 2001.

SIQUEIRA, Sueli. O retorno motivado pela crise na economia norte americana. Revista Tempo e Argumento, Florianópolis, v. 1, n. 2, jul./dez. 2009, p. 64-79.

VERTOVEC, Steven. Super-diversity and its implications. Ethnic and Racial Studies, v. 30, 2007, p. 1024-1054.

WIMMER, Andreas; GLICK-SCHILLER, Nina. Methodological nationalism and 
beyond: nation-state building, migration and the social sciences. Global Networks v. 2, n. 4. 2002, p. 301-334.

ZANINI, Maria Catarina Chitolina. Italianidade no Brasil meridional. A construção da identidade étnica na região de Santa Maria-RS. Santa Maria: EdUFSM, 2006.

\section{Abstract}

\section{Italian-Brazilians in Italy in the 21st century: "return" to the land of their ancestors, impasses and expectations}

Our objetive is to analyze, springing from an historiographic and ethnographic perspective, some situations involving Italian-Brazilians (from Rio Grande do Sul and Santa Catarina) who migrated to Italy (since the nineties of the twentieth century). We intend to understand how this process was driven by the expectation of "return" to the land of the ancestors and the symbolic aspects associated and to analyze, too, as the source category (Italian) has been thrown by the descendants migrants and the importance it played in their trajectories.

Keywords: migration, return, identities.

Recebido para publicação em 05/09/2013.

Aceito para publicação em 18/11/2013.

Received for publication in September, 05 ${ }^{\text {th }}, 2013$.

Accepted for publication in November, 18 2013.

ISSN impresso: 1980-8585

ISSN eletrônico: 2237-9843 